\title{
Bacterial diseases of grapevine
}

\author{
Szegedi, E. ${ }^{{ }^{*}}$ \& Civerolo, E. L. ${ }^{2}$ \\ ${ }^{1}$ Corvinus University of Budapest, Institute for Viticulture and Enology, Experimental Station of Kecskemét, \\ H-6001 Kecskemét, POBox 25, Hungary \\ ${ }^{2}$ USDA-ARS, San Joaquin Valley Agricultural Sciences Center, 9611 So. Riverbend Ave., Parlier, CA 93648, USA \\ *author for correspondence, e-mail: erno.szegedi@uni-corvinus.hu
}

\begin{abstract}
Summary: Grapevines are affected by three major bacterial diseases worldwide, such as bacterial blight (Xylophilus ampelinus), Pierce's disease (Xylella fastidiosa) and crown gall (Agrobacterium vitis). These bacteria grow in the vascular system of their host, thus they invade and colonize the whole plant, independently on symptom development. Latently infected propagating material is a major factor in their spreading. Therefore the use of bacteria-free planting stock has a basic importance in viticulture. Today several innovative diagnostic methods, mostly based on polymerase chain reaction, are available to detect and identify bacterial pathogens of grapevines. For production of bacteria-free plants, the use hot water treatment followed by establishment of in vitro shoot tip cultures is proposed.
\end{abstract}

Keywords: Agrobacterium vitis, bacterial blight, crown gall, Pierce's disease, Vitis vinifera, Xylella fastidiosa, Xylophilus ampelinus

\section{Grapevine as a host for bacteria}

Bacteria require several environmental factors for their in planta growth, including availability of appropriate nutrients, optimal $\mathrm{pH}$, relative humidity and temperature. Grapevine xylem sap contains large amounts of various inorganic and organic compounds including sugars (glucose, fructose) organic acids (tartrate, malate, citrate) and the complete range of amino acids of which glutamine may reach $90 \%$ of total amino acid content (Andersen \& Brodbreck 1989, Glad et al. 1992, Prima-Putra \& Botton 1998, RoubelakisAngelakis \& Kliewer 1979). The $\mathrm{pH}$ varied between 5.7 and 6.9 (Glad et al. 1992, Roubelakis-Angelakis \& Kliewer 1979) which is appropriate for several microbes. Among the organic acids, tartrate is a characteristic compound of grapevine (Ruffner 1982). These materials serve as potential nutrients for, and support the growth of a wide range of bacteria. In a Canadian survey, the number of endophytic bacterial cells in xylem fluid exceeded $10^{4}$ cells $/ \mathrm{ml}$. Most of them were Gram-negative bacteria in the genera Pseudomonas and Enterobacter (Bell et al. 1995). The nutrient-rich environment of grapevine also provide favourable conditions for bacterial pathogens, that is they are able to use the nutrient sources provided by this host. For example, the ability of Agrobacterium vitis to utilize tartrate contributes to its association with grapevines (Kado 1998, Salomone et al. 1998). Tartrate utilization by Xylophilus ampelinus in vitro has also been reported; however, its role in the host specialization of this pathogen has not been documented yet (Dreo et al. 2005, Willems \& Gillis 2006). Other xylem compounds, e. g., glucose, citrate and glutamine support the growth of Xylella fastidiosa subsp. fastidiosa in vitro (Almeida et al. 2004, de Macedo Lemos et al. 2003).
Besides providing nutrients, grapevine sap contains certain, yet undetermined signal compound(s), which induce(s) a differential gene expression in X. fastidiosa subsp. fastidiosa resulting in biofilm formation (Shi et al. 2010, Zaini et al. 2009).

\section{General features of bacterial diseases}

Among grapevine diseases, those caused by various bacterial species are significantly important in most grapegrowing countries. They are characterized by relatively slow symptom development compared to foliar and fruit cluster diseases caused by fungi (e. g., downy mildew, powdery mildew, grey mold). Chemical or biological control methods, that could efficiently prevent symptom development are not available for bacterial diseases. Bacterial pathogens associated with grapevine diseases occur in the vascular system and intercellular spaces of their host plant and they can be cultivated on laboratory media. Thus their detection, identification and use for experimental purposes is far easier than those of obligate parasites. All bacteria causing grapevine disease are systemic in the vascular tissues, and this frequently leads to latent infections. A. vitis and $X$. fastidiosa subsp. fastidiosa produce polygalacturonases, plant cell wall degrading enzymes, that virulence factors facilitate bacterial spread in the xylem (RodriguezPalenzuela et al. 1991, Roper et al. 2007). Indeed, Pierce's disease symptom development was delayed in grapevine plants which expressed a polygalacturonase-inhibiting protein gene (Agüero et al. 2005). A consequence of their systemic nature is that they are disseminated by propagating material. Therefore, use of healthy plant stocks for grapevine 
propagation is a basic prerequisite for minimizing economic losses caused by these bacterial pathogens.

Three major bacterial diseases are known in several grapevine-growing countries worldwide. These are bacterial blight (X. ampelinus), Pierce's disease (X. fastidiosa subsp. fastidiosa) and crown gall (A. vitis). These bacteria live in close association with their grapevine host and (in the case of $X$. fastidiosa subsp. fastidiosa) with their insect vector. The sporadic occurrence of Pseudomonas sp. (Whitelaw-Weckert et al. 2011) and Xanthomonas sp. (Burr \& Hurwitz 1980) associated with inflorescence decay and leaf necrosis, respectively, have also been described. However, their economic importance in viticulture has not been conclusively determined, therefore we do not discuss them in detail here.

\section{Bacterial blight}

This disease is also known as bacterial necrosis. Bacterial blight is caused by $X$. ampelinus, a Gram negative bacterium that is a member of the Class $\beta$-Proteobacteria. The bacterium infects grapevines through wounds or natural openings, such as stomata and hydrathodes. On the stems longitudinal reddishbrown streaks usually appear that develop into cankers. Leaves may be infected via the petioles and veins resulting in death of the whole leaf. When infection occurs through the stomata, $X$. ampelinus cause local necrotic symptoms.

Bacterial blight occurs mainly in the Mediterranean region of Europe (Italy, Greece, Spain), in South Africa and more recently in Slovenia (Dreo et al. 2005, Grall \& Manceau 2003, OEPP/EPPO 2009, Serfontein et al. 1997). Isolates derived from different sources show very little physiological and biochemical differences (Dreo et al. 2005, Willems \& Gillis 2006). The physiological and molecular bases for virulence of $X$. ampelinus have not been determined.

$X$. ampelinus is closely associated with grapevine. No other host plant or intermediate vector has been described. Infected propagating material is the primary source of its dissemination. Therefore, diseased plants should be removed from plantations. Resistant Vitis species and $V$. vinifera varieties are not known.

\section{Pierce's disease}

Pierce's disease is caused by X. fastidiosa subsp. fastidiosa, a Gram-negative bacterium that belongs to the Class $\gamma$-Proteobacteria. The leaves become brown, beginning at the tips and margins, and progress inward. Necrotic lesions usually are surrounded by a yellow border that separates the brown and green leaf tissues. As the disease develops, leaves drop prematurely so that the petioles remain attached to the stem, appearing like ,matchsticks”. Hot and arid weather increases symptom development that finally lead to decline.

Pierce's disease of grapevine is common in the southern part of USA, in Central America and in South America including some islands in the Caribbean region (Aguilar et al. 2008, McGaha et al. 2007, Stover et al. 2008). A few reports describe Pierce's disease in Europe (Berisha et al. 1998, Boubals 1989), although it has, so far, not become epidemic probably due to the lack of appropriate vectors.

During the disease progression, the pathogen invades the grapevine xylem where it attachs to the plant cell wall. The bacterium extensively colonizes these vascular elements forming biofilms in the xylem vessels. This process finally leads to xylem occlusion resulting in blockage of water and nutrient transport (Chatterjee et al. 2008). The pathogen has an extremely wide host range. Besides grapevine, $X$. fastidiosa subsp. fastidiosa occurs in several wild plant species that highly promote its survival and spread (Costa et al. 2004, McGaha et al. 2007). X. fastidiosa subsp. fastidiosa cells are transmitted from infected plants to healthy ones by xylem-feeding insects, e. g., leafhoppers and sharpshooters. To reduce economic losses caused by Pierce's disease, it is necessary to remove diseased grapevines from the plantation and potential host plants (weeds) from areas closely surrounding vineyards, and to apply insecticides to control vectors. European (V. vinifera) grapevine cultivars are susceptible to this disease, but a few native American Vitis species (e. g., V. aestivalis, V. arizonica) are resistant (Krivanek et al. 2006).

\section{Crown gall}

Crown gall disease is caused by the Gram-negative bacteria $A$. vitis, and occassionally by Agrobacterium tumefaciens (Burr et al. 1998, Palacio-Bielsa et al. 2009a, Szegedi et al. 2005). The genus Agrobacterium belongs to the Class $\alpha$-Proteobacteria. Pathogenic agrobacteria contain large plasmids called Ti plasmids (pTis) that carry the genes for their tumorigenicity. pTis of A. vitis form three distinct groups on the basis of their opine-inducing ability, as octopine/cucumopine, nopaline and vitopine groups (Burr et al. 1998). Opines are various amino acid derivatives produced exclusively in crown gall tumors. Plant tumors secrete these compounds which are selective carbon and energy sources for the inducing agrobacteria. Besides pTis, A. vitis cells contain an additional large plasmid coding for tartrate utilization, that contributes to the adaptation of A. vitis to grapevine (see above).

In nature, tumors always appear on the woody parts of the infected grapevines. They may cover the whole surface of trunk, or arise from local wounds exhibiting a cauliflowerlike morphology. Natural symptoms on young, green shoots have not been reported. Since they are highly susceptible to infection, the absence of crown galls on young stems may be explained by the bacterium-free status of the green shoots.

This disease causes economic losses not only in the plantations but in nurseries as well. Crown gall is the most widely distributed bacterial disease of grapevine. Its occurrence has been reported in nearly all grape-growing regions of the world, including several European countries. 
During crown gall tumorigenesis, a part of the pTi plasmid, called T-DNA, is transferred from the bacterium to the plant cell, and it becomes integrated the host plant's chromosomal genome. Expression of T-DNA genes in the plant cells results in two basic physiological changes. First, undifferenciated cell division occurs as a result of hormonal overproduction. Second, tumorous cells produce specific amino acid derivatives (opines). The type of opines produced by crown galls is determined by the inducing Agrobacterium. Details on the molecular basis of crown gall tumorigenesis have been reviewed (Gelvin 2009, 2010, Tzfira \& Citovsky 2008,).

A. vitis, like $X$. ampelinus, is closely associated with grapevines. The occurence of this bacterium in other plants or in virgin soils has not been reported. Similarly, vectors that disseminate $A$. vitis are not known. Although nematodes promote agrobacterium infection of grapevine (Süle et al. 1995), it is not known if they can mediate the transmission of this bacterium from one plant to another. European grapevines ( $V$. vinifera) are susceptible to Agrobacteriuminfection, but certain rootstock varieties derived from Vitis riparia (Gloire de Montpellier, 3309C) show high levels of resistance to tumorigenesis (Süle et al. 1994). Certain V. amurensis genotypes were also reported to be resistant, and that resistance was inherited by a simple Mendelian way (Szegedi \& Kozma 1984).

\section{Production of bacteria-free grapevine stocks}

As noted above, the use of healthy planting material is a key factor for preventing the spread of bacterial pathogens of grapevine. Bacteria-free grapevine stocks can be selected by visual selection of symptom-free true-to-type plants; indexing existing plant material for the presence of pathogens; and laboratory assays. In recent years, polymerase chain reaction (PCR)-based protocols have become increasingly predominant for detection and diagnosis of bacterial plant pathogens. This method amplifies relatively short (usually 200-1000 bp) specific genomic sequences determined by homologous ,starter"sequences, called primers, that direct forward and reverse DNA synthesis. Although the method is highly sensitive and specific, it still has limiting factors, that must be considered for the application of PCR. These include the presence of polymerase-inhibitors in DNA samples, uneven distribution of the pathogen is the host plant, or genetic diversity of the target pathogen. To test plant propagating materials for the presence of bacterial pathogens, total DNA can be isolated (1) directly from the plant or (2) from the isolated (purified) bacterial colonies grown on artificial nutrient media. Although the latter method takes some additional days or even weeks, it is much more reliable than the first method since isolation of bacterial colonies eliminates several polymerase inhibitors (polysaccharides, polyphenols) that occur in extracts of plant tissue samples, as well as results in enrichment of the target pathogen. Due to their very slow growth, in vitro isolation of $X$. ampelinus and $X$. fastidiosa subsp. fastidiosa may still be difficult, since endophytic bacteria that grow faster than the these pathogens may overgrow them in vitro on nutrient agar during isolation. Methods for isolation of these grapevine pathogens have been described, e. g., by Dreo et al. (2005), Serfontein et al. (1997) and Willems \& Gillis (2006) for X. ampelinus, and by Aguilar et al. (2008), Almeida et al. (2004) and Fry et al. (1990) for X. fastidiosa subsp. fastidiosa. Some authors prefer gellan gum (GelRite) to agar as gelling agent in the nutrient medium for isolation of $X$. fastidiosa subsp. fastidiosa (Almeida et al. 2004).

Several conventional and real-time PCR-based protocols have been described for the detection and identification of these bacterial pathogens (Hren et al. 2010, Palacio-Bielsa et al. 2009b). The application of multiplex PCR allows the identification of genetically diverse types of bacteria in a single reaction (Bini et al. 2008, Kawaguchi et al. 2005, Pulawska et al. 2006), while the use nested or semi-nested PCR (Peduto et al. 2010, Pulawska \& Sobiczewski 2005) increases the specificity and sensitivity of detection. Introduction of simple nucleic acid sampling tools, such as FTA cards (Grund et al. 2010) and loop mediated isothermal amplification, for plant disease diagnosis (Harper et al. 2010) allows simple sample collection and rapid pathogen detection without the need for expensive laboratory equipment and other related costs.

Despite of the availability of highly sophisticated molecular diagnostic and detection protocols, these methods alone are not always appropriate for reliable selection of pathogen-free propagating material due to the uneven distribution of bacterial cells in the host plant. Thus, there is a need also for efficient curative methods that are able to eliminate pathogens completely from plant stocks.

Due to the systemic nature of bacterial infection in grapevine propagating material, chemical treatments are insufficient to kill endophytic bacteria in canes. Hot water treatment (HWT; immersion of dormant canes in water at 50 ${ }^{\circ} \mathrm{C}$ for 30 mins) eliminated the Pierce's bacterium, $X$. fastidiosa subsp. fastidiosa so that no symptom development was observed for two years following treatment (Goheen et al. 1973). The level of X. ampelinus cells was also reduced below the detection limit in grapevine canes using HWT (Psallidas \& Argyropoulou 1994). However, these results have not been confirmed. A. vitis, surviving in dormant grapevine cutting was only partially eliminated by HWT since treated canes still contained some surviving pathogen cells (Burr et al. 1996). Since HWT kills several other pathogens (e. g., phytoplasmas) and pests (mites, nematodes, etc.), it is advisable to pass propagating material through this treatment.

Grapevine plants which are completely free from Agrobacterium spp. and $X$. fastidiosa subsp. fastidiosa are achieved by establishing in vitro cultures started from apical meristems or shoot tips (Burr et al. 1988, Robacker \& Chang 1992, Thies \& Graves 1992). In practice, plant material for in vitro cultures is started from hot water-treated canes as 
described above to ensure, as much as possible, pathogen-, and pest-elimination. Rooted plants can be multiplied in vitro and acclimatized for greenhouse and field growth. Details of this process are shown on Figure 1. In spite of the fact that plant lines obtained by this way are usually sterile, they should be tested by one or more of the diagnostic methods described above to ensure they are really bacteria-free. Such lines then can be used to establish stock plantations for large scale propagation.

\section{Acknowledgements}

E. Szegedi was supported by the HU-SRB 0901/214/123 EU project.

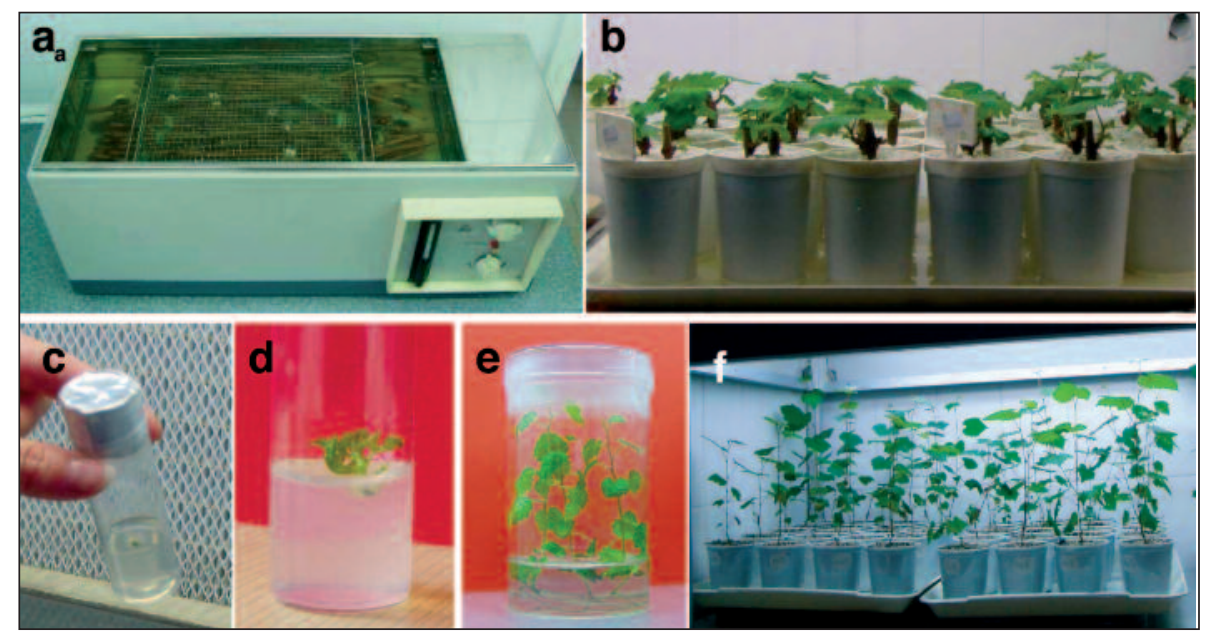

Figure 1. Process of production of bacteria-free plants. (a) Canes are hot water-treated at $52{ }^{\circ} \mathrm{C}$ for 45 mins, (b) followed by shooting in perlite which is practically a sterile medium. Shoot tips are removed, disinfested and (c) approximately $0.5-1.00 \mathrm{~mm}$ long tip pieces are used to start in vitro cultures on Murashige-Skoog medium with $0.5 \mathrm{mg} / \mathrm{l}$ benzyl-adenine. (d) small shoots are transferred (e) to hormonefree medium to root and (f) finally the plantlets are acclimatized to greenhouse conditions.

\section{References}

Agüero, C. B., Uratsu, S. R., Greve, C., Powell, A. L. T., Labavitch, J. M., Meredith, C. P. \& Dandekar, A. M. (2005): Evaluation of tolerance to Pierce's disease and Botrytis in transgenic plants of Vitis vinifera L. expressing the pear PGIP gene.

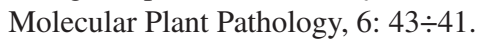

Aguilar, E., Moreira, L. \& Riviera, C. (2008): Confirmation of Xylella fastidiosa infecting grapes Vitis vinifera in Costa Rica. Tropical Plant Pathology, 33: 444 $\div 448$.

Almeida, R. P. P., Mann, R. \& Purcell, A. H. (2004): Xylella fastidiosa cultivation on a minimal solid defined medium. Current Microbiology, 48: 368-372.

Andersen, P. C. \& Brodbeck, V. (1989): Chemical composition of xylem exudate from bleeding spurs of Vitis rotundifolia Noble and Vitis hybrid Suwannee in relation to pruning date. American Journal of Enology and Viticulture, 40: 155-160.

Bell, C. R., Dickie, G. A., Harvey, W. L. G. \& Chan, J. W. Y. F. (1995): Endophytic bacteria in grapevine. Canadian Journal of Microbiology, 41: 46-53.

Berisha, B., Chen, Y.D., Zhang, G.Y., Xu, B.Y. \& Chen, T. A. (1998): Isolation of Pierce's disease bacteria from grapevines in Europe. European Journal of Plant Pathology 104, 437-433.

Bini, F., Kuczmog, A., Putnoky P., Otten, L., Bazzi, C., Burr, T. J. \& Szegedi, E. (2008): Novel pathogen-specific primers for the detection of Agrobacterium vitis and Agrobacterium tumefaciens. Vitis, 47: 181-189.

Boubals, D. (1989): La maladie de Pierce arrive dans les vignobles d'Europe. Progrès Agricole et Viticole, 106: 85-87.

Burr, T. J. \& Hurwitz, B. (1980): Leaf spot of Vitis vinifera L. caused by Xanthomonas sp. Plant Disease, 64: 698-700.

Burr, T. J., Katz, B. H., Bishop, A. L., Meyers, C. A. \& Mittak, V. L. (1988): Effect of shoot age and tip culture propagation of grapes on systemic infestations by Agrobacterium tumefaciens biovar 3. American Journal of Enology and Viticulture, 39: 67-70.

Burr, T. J., Reid, C. L., Splittstoesser, D. F. \& Yoshimura, M. (1996): Effect of heat treatment on grape bud mortality and survival of Agrobacterium vitis in vitro and in dormant grapevine cuttings. American Journal of Enology and Viticulture, 47: 119-123.

Burr, T. J., Bazzi, C., Süle, S. \& Otten, L. (1998): Crown gall of grape: Biology of Agrobacterium vitis and the development of disease control strategies. Plant Disease, 82: 1288-1297.

Chatterjee, S., Almeida, R. P. P. \& Lindow, S. (2008): Living in two worlds: the plant and insect lifestyles of Xylella fastidiosa. Annual Review of Phytopathology, 46: 243-271.

Costa, H. S., Raetz, E., Pinckard, T. R., Gispert, C., HernandezMartinez, R., Dumenyo, C. K. \& Cooksey, D. A. (2004): Plant hosts of Xylella fastidiosa in and near Southern California vineyards. Plant Disease, 88: 1255-1261.

de Macedo Lemos, E. G., Alves, L. M. C. \& Campanharo, J. C. (2003): Genomics-based design of defined growth media for the plant pathogen Xylella fastidiosa. FEMS Microbiology Letters, 219: 39-45.

Dreo, T., Seljak, G., Janse, J. D., van der Beld, I., Tjou-Tam-Sin, L., Gorkink-Smits, P. \& Ravnikar, M. (2005): First laboratory confirmation of Xylophilus ampelinus in Slovenia. EPPO Bulletin, 35: 149-155.

Fry, S. M., Milholland, R. D. \&Huang, P.-Y. (1990): Isolation and growth of strains of Xylella fastidiosa from infected grapevines on nutrient agar media. Plant Disease, 74: 522-524.

Gelvin, S. B. (2009): Agrobacterium in the genomic age. Plant Physiology, 150: 1665-1676.

Gelvin, S. B. (2010): Plant proteins involved in Agrobacteriummediated genetic transformation. Annual Review of Phytopathology, 48: 45-68.

Glad, C., Regnard, J. L., Querou, Y., Brun, O. \& MorotGaudry, J. F. (1992) : Flux and chemical composition of xylem exudates from Chardonnay grapevines: temporal evolution and effect of recut. American Journal of Enology and Viticulture, 43: 275-282.

Goheen, A. C., Nyland, G. \& Lowe, S. K. (1973): Association of a Rickettsialike organism with Pierce's disease of grapevines and alfalfa dwarf and heat therapy of the disease on grapevines. Phytopathology, 63: 341-345. 
Grall, S. \& Manceau, C. (2003): Colonization of Vitis vinifera by a green fluorescence protein-labeled, $g f p$-marked strain of Xylophilus ampelinus, the causal agent of bacterial necrosis of grapevine. Applied and Environmental Microbiology, 69: 1904-1912.

Grund, E., Darissa, O. \& Adam, G. (2010): Application of FTA ${ }^{\circledR}$ cards to sample microbial plant pathogens for PCR and RT-PCR. Journal of Phytopathology, 158: 750-757.

Harper, S. J., Ward, L. I. \& Clover, G. R. G. (2010): Development of LAMP and real-time PCR methods for the rapid detection of Xylella fastidiosa for quarantine and field applications. Phytopathology, 100: 1282-1288.

Hren, M., Dreo, T., Erjavec, J., Nikolic, P., Boben, J., Gruden, K., Dermastia, M., Camloh, M. \& Ravnikar, M. (2010): Realtime detection methods for economically important grapevine related bacteria. pp.: 229-246 in: Delrot, S., Medrano, H., Or, E., Bavaresco, L. \& Grando, S., eds., Methodologies and Results in Grapevine Research, Springer Science+Business Media B. V.

Kado, C. I. (1998): Origin and evolution of plasmids. Antonie van Leeuwenhoek, 73: 117-126.

Kawaguchi, A., Sawada, H., Inoue, K. \& Nasu, H. (2005): Multiplex PCR for the identification of Agrobacterium biovar 3 strains. Journal of General Plant Pathology, 71: 54-59.

Krivanek, A. F., Riaz, S. \& Walker, M. A. (2006): Identification and molecular mapping of PdR1, a primary resistance gene to Pierce's disease in Vitis. Theoretical and Applied Genetics, 112: $1125-1131$

McGaha, L. A., Jackson, B., Bextine, B., McCullough, D. \& Morano, L. (2007): Potential plant reservoirs for Xylella fastidiosa in South Texas. American Journal of Enology and Viticulture, 58: 398-401.

OEPP/EPPO (2009): Xylophilus ampelinus. OEPP/EPPO Bulletin, 39: 403-412.

Palacio-Bielsa, A., González-Abolafio, R., Álvarez, B., Lastra, B., Cambra, M. A., Salcedo, C. I., López, M. M. \& Penyalver, R. (2009a): Chromosomal and $\mathrm{Ti}$ plasmid characterization of tumorigenic strains of three Agrobacterium species isolated from grapevine tumours. Plant Pathology, 58: 584-593.

Palacio-Bielsa, A., Cambra, M. A. \& López, M. M. (2009b): PCR detection and identification of plant pathogenic bacteria: update review of protocols (1989-2007). Journal of Plant Pathology, 91: 249-297.

Peduto, F., Marchi, G. \& Surico, G. (2010): Indexing Agrobacterium vitis in asymptomatic grapevine propagation material by two nested PCR assays. American Journal of Enology and Viticulture, 61: 102-112.

Prima-Putra, D. \& Botton, B. (1998): Organic and inorganic compounds of xylem exudates from five woody plants at the stage of bud breaking. Journal of Plant Physiology, 153: 670-676

Psallidas, P. G. \& Argyropoulou, A. (1994): Effect of hot water treatment on Xylophilus ampelinus in dormant grape cuttings. in: Lemattre, M. et al. (eds.) Plant Pathogenic Bacteria, Symposium, Versailles, France June 9-12, 1992). Colloques de l'INRA, 66: 993-998.

Pulawska, J. \& Sobiczewski, P. (2005): Development of a seminested PCR based method for sensitive detection of tumorigenic Agrobacterium in soil. Journal of Applied Microbiology, 98: 710-721

Pulawska, J., Willems, A. \& Sobiczewski, P. (2006): Rapid and specific identification of four Agrobacterium species and biovars using multiplex PCR. Systematic and Applied Microbiology, 29: 470-479.

Robacker, C. D. \& Chang, C. J. (1992): Shoot-tip culture of muscadine grape to eliminate Pierce's disease bacteria. HortScience, 27: 449-450.

Rodriguez-Palenzuela, P., Burr, T. J. \& Collmer, A. (1991): Polygalacturonase is a virulence factor in Agrobacterium tumefaciens biovar 3. Journal of Bacteriology, 173: 6547-6552.

Roper, M. C., Greve, L. C., Warren, J. G., Labavitch, J. M. \& Kirkpatrick, B. C. (2007): Xylella fastidiosa requires poygalacturonase for colonization and pathogenicity in Vitis vinifera grapevines. Molecular Plant-Microbe Interactions, 4: 411-419.

Roubelakis-Angelakis, K. A. \& Kliewer, W. M. (1979): The composition of bleeding sap from Thomson Seedless grapevines as affected by nitrogen fertilization. American Journal of Enology and Viticulture, 30: 14-18.

Ruffner, H. P. (1982): Metabolism of tartaric and malic acids in Vitis. Vitis, 21: 247-259.

Salomone, J.-Y., Szegedi, E., Cobanov, P. \& Otten, L. (1998): Tartrate utilization genes promote growth of Agrobacterium spp. on grapevine. Molecular Plant-Microbe Interactions, 11: 836-838.

Serfontein, S., Serfontein J. J., Botha W. J. \& Staphorst, J. L. (1997): The isolation and characterization of Xylophilus ampelinus. Vitis, 36: 209-210.

Shi, X., Bi, J., Morse, J. G., Toscano, N. C. \& Cooksey, D. A. (2010): Differential expression of genes of Xylella fastidiosa in xylem fluid of citrus and grapevine. FEMS Microbiology Letters, 304: 82-88.

Stover, E., Riaz, S. \& Walker, M. A. (2008): PCR screening for Xylella fastidiosa in grape genebank accessions collected in the SE US. American Journal of Enology and Viticulture, 59: 437-439.

Süle, S., Mozsár, J. \& Burr, T. J. (1994): Crown gall resistance of Vitis spp. and grapevine rootstocks. Phytopathology, 84: 607-611.

Süle, S., Lehoczky, J., Jenser, G., Nagy, P. \& Burr, T. J. (1995): Infection of grapevine roots by Agrobacterium vitis and Meloidogine hapla. Journal of Phytopathology, 143: 169-171.

Szegedi, E. \& Kozma P. (1984): Studies on the inheritance of resistance to crown gall disease of grapevine. Vitis, 23: 121-126.

Szegedi, E., Bottka, S., Mikulás, J., Otten, L. \& Süle, S. (2005): Characterization of Agrobacterium tumefaciens strains isolated from grapevine. Vitis, 44: 49-54.

Thies, K. L. \& Graves Jr., C. H. (1992): Meristem micropropagation protocols for Vitis rotundifolia Michx. HortScience, 27: 447-449.

Tzfira, T. \& Citovsky, V., eds. (2008): Agrobacterium: from biology to biotechnology. Springer Science+Business Media LLC.

Whitelaw-Weckert, M. A., Whitelaw, E. S., Rogiers, S. Y., Quirk, L., Clark, A. C. \& Huang C. X. (2011): Bacterial inflorescence rot of grapevine caused by Pseudomonas syringae pv. syringae. Plant Pathology, 60: 325-337.

Willems, A. \& Gillis, M. (2006): Xylophilus. In: Dworkin, M., Falkow, S., Rosenberg., E., Schleifer, K.-H. \& Stackebrandt, E. eds., The Prokaryotes, 6: 741-745, Springer Science+Business Media LLC

Zaini, P. A., De La Fuente, L., Hoch, H. C. \& Burr, T. J. (2009): Grapevine xylem sap enhances biofilm development by Xylella fastidiosa. FEMS Microbiology Letters, 295: 129-134. 